\title{
Laryngopyocoele: an unusual cause of airway obstruction
}

\author{
Oliver McLaren, Simon Hickey
}

Department of ENT, South Devon NHS Foundation Trust, Torquay, Devon, UK

\section{Correspondence to} Dr Oliver McLaren, oliver.mclaren@nhs.net

Accepted 16 January 2016
CrossMark

To cite: McLaren 0 , Hickey S. BMJ Case Rep Published online: [please include Day Month Year] doi:10.1136/bcr-2016214368

\section{DESCRIPTION}

An 88-year-old woman presented with a 2-day history of dysphagia, hoarseness and inspiratory stridor. Examination revealed well-defined soft lobulated masses anteriorly and to the right of her neck. Flexible-nasendoscopy demonstrated a large mass displacing the right false-cord and compressing the epiglottis. She had good air entry to all lung fields and laboratory testing revealed a slight rise in white cell counts only.

With radiological investigation pending, she became increasingly stridulous with markedly increased work of breathing. An epinephrine nebuliser gave transient improvement only. Repeat nasendoscopy revealed near total airway occlusion (figure 1); with the clear rapid increase in swelling it was felt that an urgent tracheostomy was the safest intervention. The patient consented to urgent tracheostomy and panendoscopy with excision/ biopsy pending intraoperative findings; this was based on the presumptive diagnosis of malignancy.

Intra-operatively, the laryngeal mass was found to communicate with the neck-lumps. Mucosal incision presented a cystic structure (figure 2), which-during mobilisation and excision-burst, revealing purulent contents (figure 3), and confirming the diagnosis of a mixed-type laryngopyocoele, due to the external as well as internal components of the mass. This was excised completely.

The patient was fed via nasogastric-tube for 1 week, allowing healing of the resultant cavity (figure 4). Decannulation of tracheostomy occurred after 6 days, without complication; a swallow assessment confirmed no aspiration and the nasogastric tube was removed. Once adequate oral intake was confirmed over the following 2 days, the patient was discharged with follow-up at 1 week. At follow-up, tracheostomy and cystic cavity were both fully healed (2 weeks postoperatively).

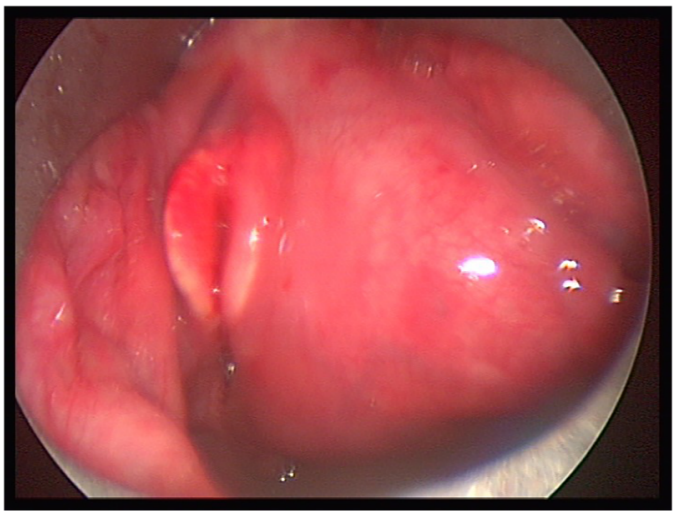

Figure 1 Airway occlusion secondary to laryngeal mass, note folded epiglottis.

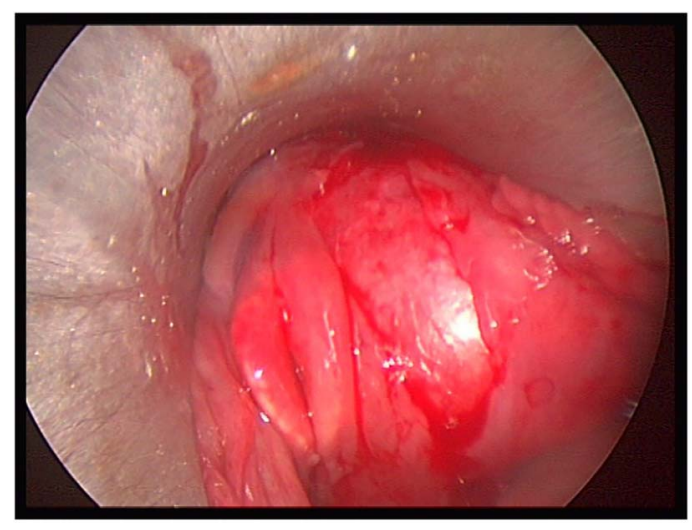

Figure 2 Incised laryngeal mucosa revealing cystic structure.

Laryngocoeles are air-filled/mucus-filled herniations of laryngeal ventricles. They affect 1 in 2.5 million people and are five times more prevalent

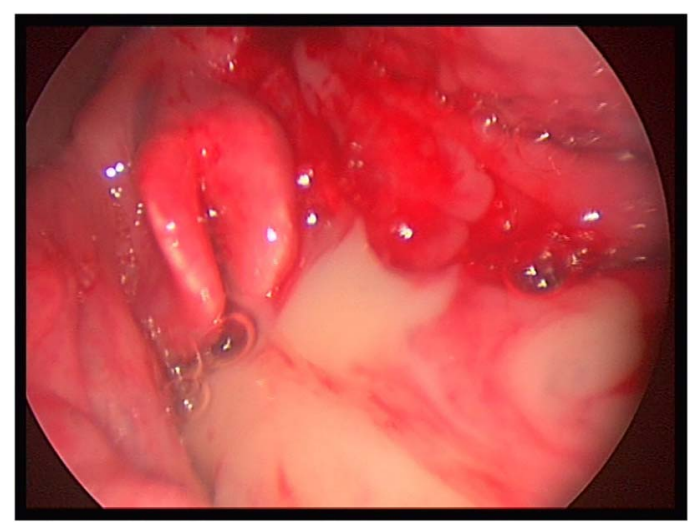

Figure 3 Purulent contents confirming laryngopyocoele.

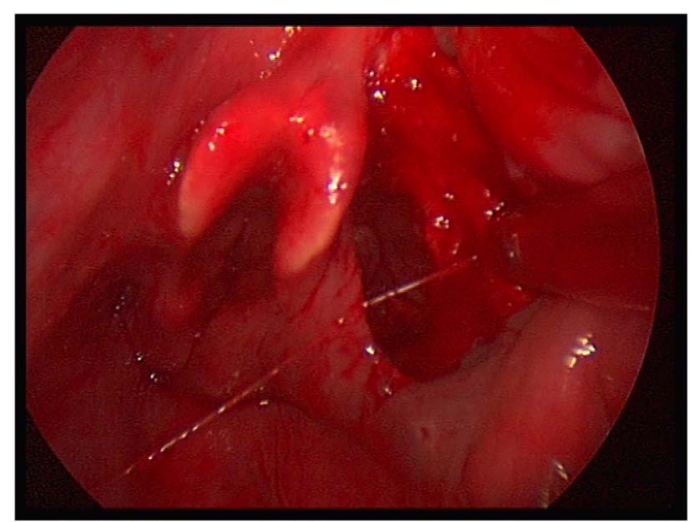

Figure 4 Cavity following complete excision. 


\section{Learning points}

- Laryngopyocoeles are a rare cause of airway obstruction requiring a high index of suspicion to make the diagnosis. As in this case, symptoms can progress rapidly with worsening infection leading to increasing airway obstruction, so early involvement of ear, nose and throat (ENT) teams is vital. With this patient, the clinical progression necessitated treatment prior to radiological investigation. Contrast CT scanning is the ideal first-line imaging modality of choice. ${ }^{2}$ Any patient presenting with stridor should be reviewed by ENT.

- Initial management requires ensuring a safe airway and decompression of the obstructing laryngopyocoele. Complete excision should be performed initially or at a later date, ${ }^{3}$ to avoid re-accumulation; this can be performed endoscopically or via an external approach.

- Typical pathogens are: Pseudomonas aeruginosa, Staphylococcus aureus, Eschericia coli and Haemolyitic streptococcus. Therefore, broad-spectrum antibiotic cover is important, followed by culture-specific antibiotics when results become available. ${ }^{3}$ in males, generally presenting in the sixth decade of life. ${ }^{1}$ There is thought to be an association with malignancy, as well as congenital and acquired factors, but exact aetiology is unknown.

They are defined anatomically as internal, external or combined/mixed. ${ }^{2}$ Mucus accumulates in obstructed laryngocoeles, which when infected produce pus. There have been 39 reported cases of laryngopyocoele and only five previous cases leading to airway obstruction. ${ }^{3}$

Contributors Initial write up was performed by OM with critical review provided by SH.

Competing interests None declared.

Patient consent Obtained.

Provenance and peer review Not commissioned; externally peer reviewed.

\section{REFERENCES}

1 Stell PM, Maran AG. Laryngocoele. J Laryngol Otol 1975;89:915-24.

2 Koeller KK, Alamo L, Adair CF, et al. Congenital cystic masses of the neck: radiologic-pathologic correlation. Radiographics 1999;19:121-46; quiz 152-3.

3 Vasileiadis I, Kapetanakis S, Petousis A, et al. Internal laryngopyocele as a cause of acute airway obstruction: an extremely rare case a review of the literature. Acta Otorhinolaryngol Ital 2012;32:58-62.

Copyright 2016 BMJ Publishing Group. All rights reserved. For permission to reuse any of this content visit

http://group.bmj.com/group/rights-licensing/permissions.

BMJ Case Report Fellows may re-use this article for personal use and teaching without any further permission.

Become a Fellow of BMJ Case Reports today and you can:

- Submit as many cases as you like

- Enjoy fast sympathetic peer review and rapid publication of accepted articles

- Access all the published articles

- Re-use any of the published material for personal use and teaching without further permission

For information on Institutional Fellowships contact consortiasales@bmjgroup.com

Visit casereports.bmj.com for more articles like this and to become a Fellow 